Журнал «Герспективитаінновації наукиљ

(Серія«Гедагогіка»), Серія«ГТихологія», Серія «Медицина»

№5(5) 2021

УДК 373.21(71)

https://doi.org/10.52058/2786-4952 -2021-5(5)-554-563

Рудницька-Юрійчук Ірина Романівна кандидат педагогічних наук, асистент кафедри педагогіки та психології дошкільної освіти, факультет педагогіки, психології та соціальної роботи, Чернівецький національний університет імені Юрія Федьковича, вул. Рівненська, 14, м. Чернівці, тел.: (0372) 509431 , e-mail: i.rudnytska-iuriichuk@chnu.edu.ua, https://orcid.org/0000-0003-0876-7751

\title{
МАРІЯ ПАСТЕРНАКОВА - ПЕДАГОГ, ВИХОВАТЕЛЬ ДОШКІЛЛЯ В УКРАЇНСЬКІЙ ДІАСПОРІ КАНАДИ
}

Анотація. На сучасному етапі розвитку України, в умовах докорінних соціально-економічних трансформацій та глобалізації міжнародного освітнього простору кардинальних змін зазнає й вітчизняна система освіти.

Основи ㄲï становлення закладаються в системі дошкільної освіти, діяльність якої повинна відповідати вимогам держави й суспільства, соціальнокультурним потребам сім’ї щодо виховання дітей дошкільного віку, створювати комфортне середовище для їхнього гармонійного всебічного розвитку, вироблення життєво важливих компетентностей.

Перспективні напрями розвитку і шляхи вдосконалення дошкільної освіти в Україні визначено в законах України «Про освіту» (2017) та «Про дошкільну освіту» (2001), Національній доктрині розвитку освіти України у XXI столітті (2002), Концепції національно-патріотичного виховання дітей та молоді (2015), «Базовому компоненті дошкільної освіти» (2021) та інших законодавчих i нормативно-правових документах. Вирішення окреслених у них завдань можливе за умови грунтовного вивчення i творчого використання ідей i досвіду, накопиченого закладами дошкільної освіти України в різні історичні періоди, а також за іiі межами, зокрема у Канаді, де проживає понад 11,3\% закордонних українців i, найголовніше, діють найдавніші i найпотужніші українські діаспори з розгалуженою системою національної освіти й виховання підростаючих поколінь. Необхідно враховувати й те, що зарубіжні українці сьогодні є важливим інтелектуальним, демографічним, етносоціокультурним та інформаційним ресурсом нашої держави й ефективним чинником творення іiі позитивного іміджу у світовому часопросторі.

Теоретико-методичні засади української дошкільної освіти і виховання в Канаді складають ідеї, положення i рекомендації, викладені в працях Горохович, 1992; Жарського, 1965; Климишин, 1969; Лещишин, 1980; Мацьківа, 1966; Мончак, 1965; Назарка, 1961; Пеленської, 1966; Петрів, 1965; Чумака Р., \& Чумака Я., 1977; інших педагогів, учених, виховників, громадських діячів української діаспори у цій країні. 
Ключові слова: виховання, діаспора, діти дошкільного віку, методичні рекомендації, українське дошкілля.

Rudnytska-Yuriichuk Iryna Romanivna Ph.D in Pedagogical Sciences, Assistant of Department of Pedagogy and Psychology Preschool, Faculty of Pedagogy, Psychology and Social Work, Yuriy Fedkovych Chernivtsi National University, Chernivtsi, Rivnens`ka St., 14, tel.: (0372) 5094 31, e-mail: i.rudnytska-iuriichuk@chnu.edu.ua, https://orcid.org/0000-0003-0876-7751

\section{MARIYA PASTERNAKOVA - TEACHER, PRESCHOOL TEACHER IN THE UKRAINIAN DIASPORA OF CANADA}

Abstract. At the present stage of Ukraine development, in the conditions of radical socio-economic transformations and globalization of the international educational space, the national education system suffers essential changes.

Its formation foundations are laid in the system of preschool education, the activities of which must meet the requirements of the state and society, socio-cultural needs of the family to educate preschool children, create a comfortable environment for their harmonious and balanced growth and vital competencies development.

Promising directions of the development and ways to improve preschool education in Ukraine are defined in the laws of Ukraine «On Education» (2017) and «On Preschool Education» (2001), the National Doctrine of Education of Ukraine in the XXI century (2002), the Concept of national and patriotic education of children and youth (2015), «Basic component of preschool education» (2021) and other legislative and legal documents. The solution of the outlined tasks is possible under the condition of thorough study and creative use of ideas and experience gained by preschool education institutions of Ukraine in different historical periods, as well as abroad, in particular in Canada, where more than 11,3\% of Ukrainians live abroad and, most importantly, there are the oldest and most powerful Ukrainian diasporas with an extensive system of national education and upbringing the younger generations. It is necessary to consider that Ukrainians abroad, today is an important intellectual, demographic, ethno-sociocultural and information resource of our state and an effective factor in creating its positive impression about Ukraine in the world time space.

Theoretical and methodological principles of Ukrainian preschool education and upbringing in Canada are the ideas, provisions and recommendations highlighted in the works of Gorokhovych, 1992; Zharskyi, 1965; Klymyshyn, 1969; Leshchyshyn, 1980; Matskiv, 1966; Monchak, 1965; Nazarko, 1961; Pelenska, 1966; Petriv, 1965; Chumak R., \& Chumak Ya., 1977; other teachers, scientists, educators, public figures of the Ukrainian diaspora in this country.

Keywords: education, diaspora, preschool children, methodical recommendations, Ukrainian preschool. 
Журнал«Герспективитаінновації наукиљ

(Серія«Гедагогіка», Серія«ГЕихологія», Серія «Медицин»

№5(5) 2021

Постановка проблеми. Постать Марії Пастернак (1897-1983) $\epsilon$ маловідомою українському загалу i здебільшого згадується у контексті висвітлення життєпису та наукової діяльності піi чоловіка - Ярослава Пастернака - відомого на весь світ українського краєзнавця, археолога.

Аналіз останніх досліджень і публікацій. Цій талановитій жінці вдалося вповні реалізувати себе як літераторку, громадську діячку та публіцистку. Життєпис Марії Пастернак висвітлено у нарисі Л. Бурачинської (під псевд. Л. Бура) [1], фрагментарно творчий доробок М. Пастернак розкрито у статтях Т. Завгородньої, Р. Пахолка [3].

Варто зауважити, що у більшості цих досліджень розкрита публіцистична i мистецько-критична діяльність. Проте, для педагогів-дошкільників в українській діаспорі спадщина Марії Пастернак є набагато глибшою, оскільки вона $є$ автором методичних рекомендацій, що вийшли друком у 1959 році в Торонто (Канада) «Зайняття в дитячому садку» [1, с.9-10].

Мета статті полягає в аналізі педагогічних ідей та діяльності Марії Пастернак у галузі дошкільної освіти в українській діаспорі Канади.

Виклад основного матеріалу. Марія Пастернак належала до тих жінок, які вміли цінувати й підтримувати талант своїх обдарованих чоловіків (не раз бувала в археологічних експедиціях), водночас, вона ніколи не боялася вийти 3-під тіні відомого науковця й розвивала власний дослідницький хист і творчий потенціал. Як писала відома мистецтвознавець Лідія Бурачинська, Марії Пастернак «пощуастило кинути яркий жмут світла, а то й торувати дорогу у дві важливі ділянки - дошкільне виховання і танкове мистецтво» [1, с.9-10].

Наукові відкриття чоловіка пробудили у жінці письменницький хист і вона взялася за написання оповідань для дітей про археологічні дива, які публікувала на шпальтах журналу «Українське дошкілля»- «Синцьо в Крилосі» (під псевдонімом Тета Міка) і «Золотий Тік».

З 1934 по 1939 рік Марія Пастернакова очолює педагогічну референтуру Товариства «Українська Захоронка». Як слушно зауважила дослідниця Лідія Бурачинська, «Це був час великого росту української дошкільної справи, що започаткувалась в Україні, в часі відбудови української державності завдяки заходам Софії Русової» [1].

Поглибивши свої знання 3 дошкільного виховання, вона в період 19381939 р.р. очолювала редакцію журналу «Українське Дошкілля» та вміщувала на його сторінках статті з дошкільного виховання. У численних публікаціях на шпальтах часопису обстоювала потребу належної організації фізичного виховання у дошкільних закладах, зокрема, вважала доцільним використовувати на таких заняттях елементи ритміки та ритмічної руханки за системою Е. Жак-Далькроза (подавала зразки власних ритмічних танців 3 описом рухів) [2].

Упродовж 1941-1944 р.р. Марія Пастернак була референтом дошкільного відділу Українського Центрального Комітету у Львові, разом із помічниками працювала над розширенням мережі дошкільних закладів у Галичині, а також 
започаткуванням нових садків на Підляшші, Поліссі, Волині і Лемківщині. Вона дбала про забезпечення дитячих установ дидактичними матеріалами, книжками й іграшками; неодноразово обстоювала у пресі (під криптонімом М.П.), зокрема на шпальтах часописів «Краківські Вісті», «Львівські Вісті», «Наша Будуччина», «Українська Школа», потребу розвитку дошкільного виховання в Галичині, називаючи його міцною основою суспільства [2].

У 1943 р. на західноукраїнських землях діяло 241 постійних та 696 сезонних дитячих садків [3, с.10-14]. Оскільки в Галичині у той час бракувало кваліфікованих виховниць, Марія Пастернак вирішила написати грунтовний підручник, призначений переважно вихователям, які не мали педагогічної освіти. Але бурхливі воєнні події перешкодили сміливим видавничим планам.

Навесні 1944 року Марія Пастернак разом із чоловіком, аби уникнути ймовірного арешту, вимушено емігрували до Відня, а у травні 1949 року подружжя оселилося в Канаді, у Торонто [2].

I тільки там, в українській діаспорі, через десятиліття після написання, Об'єднання Українських Педагогів Канади опублікувало невелику частину праці М. Пастернак, що вийшла друком як окрема книга «Зайняття в дитячому садку» (Торонто, 1959), в якій авторка стисло подала методику дошкільного виховання [2]. Даний україномовний методичний посібник довгий час залишався єдиною у своєму роді «Азбукою дошкілля» [3, с.12] для українців у вільному світі [1, с.9-10].

Методичний посібник складається із дев'яти розділів:

1. Психологічні підстави виховання в дитячому садку

2. Фізичне виховання

3. Рухливі ігри

4. Драматизовані (ілюзійні) і дидактичні ігри

5. Мовні заняття

6. Спів і музика

7. Природознавство

8. Ручні праці

9. Святкові дні в дитячому садку.

Для укладання розділів посібника авторка, за словами Зенона Зеленого (голови АУП Канади), «відома із своїх теоретичних і практичних студій в дошкільній ділянці» [4, с.3], користувалася власним довголітнім досвідом та фаховою літературою, зокрема найновішими на той час педагогічними виданнями.

Вступ до посібника розпочинається з такої думки: «В історії українського шкільництва окремий розділ займає дошкільне виховання». Цими словами Марія Пастернакова підтверджує свою принципову позицію щодо важливості дошкільного виховання як фундаменту всього освітнього процесу людини. У вступному слові вона коротко розкриває питання заснування та відкриття перших дитячих садків в Україні, перелічує види садочків, які діяли на українських землях: «постійні дитячі садки», «літні дитячі садки» i, досить 
незвичний варіант дошкільних закладів, «сільські - сезонні, на час літніх робіт у полі» [4, с.3].

Марія Іванівна надає особливого значення особистості педагога дошкілля, стверджуючи, що саме ця постать є центром усієї діяльності дошкільного закладу, адже від неї залежить розвиток особистості дитини. Саме вихователь, на думку М. Пастернакової, формує «власний стиль виховної праці», від якого залежить якість виховної роботи в дитячих садках: педагогічний хист, творча ініціатива, знання складної дитячої психіки, цінності, які педагог прищеплюватиме дитині і які збережуться на все життя вихованця.

У даній праці авторка не оминає увагою важливість підготовки фахових педагогів дошкілля - «виховниць», для яких в Україні працювали окремі школи середнього типу і короткотривалі підготовчі курси [4, c.3]. Цю ж думку вона розвиває, перебуваючи уже в діаспорі. Зокрема, у своєму виступі «Який посів - так жнива» на Сесії для справ Українського дошкілля, яка відбувалася в Торонто 14-15 травня 1965 року [5], педагог наголошує, що особливу увагу слід звернути на «вишкільні» курси для майбутніх вихователів дитячих садків, на показові заняття 3 дітьми $\mathrm{i}$, не зрікаючись давнього, творити нове, осучаснене, щоб виховати українську людину завтрашнього дня. Садівничка (вихователь дошкілля в українській діаспорі) повинна постійно знайомитись не тільки з чужомовною фаховою літературою і новими здобутками в дошкільній ділянці, а й також зобов'язана знати українську дошкільну літературу i користуватися багатим досвідом попередніх етапів розвитку дошкільної освіти й виховання. «Конфронтація сьогоднішнього 3 вчорашнім із натяком на завтра, - вважає М. Пастернакова, - дасть праці тяглість, тому що кращі зразки минулого завжди запліднюють нові ідеї і діла» [5, с.27].

За іï переконаннями, вихователь, як і вчитель, не має права бути невільником якогось одного підручника чи методики, а повинен постійно поповнювати свої теоретичні і практичні знання, вносити в свою працю свіжий підхід і нові висвітлення виховних питань. Тоді він (вихователь) продовжуватиме цю важку, з погляду родинного, національного і людського, працю, записуючи нові сторінки в історії українського дошкільного виховання [4].

Серед вимог до особистості вихователя $є$ й така «виховниця мусить говорити виразною літературною мовою, коли хоче цього домогтися від дітей. М'яким приязним підходом до дитини, а не насмішливим підкреслюванням іiі мовних помилок можна не тільки навчити дитину правильно говорити, але теж виправити деякі їі мовні дефекти» [4, с.51].

«Рідну мову, - стверджує Пастернакова М., - треба любити й берегти як найбільшу цінність та плекати ііі упродовж усього життя. Перші слова мами, пісеньки, колисанки, якими вона розважає дитину, казки повинні бути у рідній мові, щоб мелодією рідного слова налилось вщерть серце дитини» [4, с.45].

Проте не тільки батьки мають вплив на формування мови та мовлення української дитини у діаспорі. На чистоту і збагачення рідної мови мають 
великий вплив усі дорослі, в оточенні яких живе дитина. Тому перед виховницями дитячого садка стоїть завдання - зробити мову дитини зрозумілою, змістовною, збагатити іiі словник та засвоїти граматичні форми. Їх особистий приклад відіграє велику роль, мова вихователя повинна бути зразкова [4, с.45-46].

У праці над розвитком дитячої мови українським виховникам варто надавати перевагу словесним методам, зокрема - груповим та індивідуальним розмовам з дітьми, адже причин та тем для них є дуже багато, особливо зранку, коли діти сходяться до дитячого садка. У цей час вони не тільки відповідають на запитання, але й самі з радістю розповідають, що вони бачили, йдучи до садка, що відбувалося вдома [4, с.46]. Завдання вихователя- уважно прислухатися до розмови дітей, щоб ті відчули щире зацікавлення їх розповіддю. До дитячих розповідей, стверджує Марія Іванівна, слід ставитися 3 увагою, підтримувати їхню вигадливість. А помилки і неточності висловів виправляти обережно, не послаблюючи захоплення дитини розповіддю [4].

Авторка методичних рекомендацій зазначає, що найбільш поширеними, апробованими та використовуваними формами i методами навчання в дошкільних українських установах у діаспорі виступають молитва й релігійні пісні та розповіді; вказівки щодо доброї поведінки; казки й оповідання; бесіди на різні теми; драматизація казок, оповідань, ляльковий театр; робота із словником української мови, вірші і пісні напам'ять; спів у хорі і в сольних виступах; музика - слухання гри дитячого оркестру; вправи 3 числення й математики; покази й експерименти 3 природознавства для опанування термінів і явищ; ручні заняття: малювання, вирізування, ліплення; виготовлення часткове або цілісне іграшок та предметів щоденного вжитку; конструювання; ігри й рухливі забави, зокрема українські фольклорні.

Як зауважує Марія Пастернакова, під час ігор, особливо драматизованих, є багато можливостей для збагачення i розвитку дитячої мови. У іграх діти викладають зміст казок i оповідань, вживаються у різні ролі. Настільні дидактичні ігри теж поповнюють новими словами дитячий словник, адже ознайомлюють з назвами різних предметів [4].

Вихователі дітей дошкільного віку в українській діаспорі переконані мистецьке слово казки дає дитині можливість відчути найглибші емоції та переживання. «Вона (казка - авт.) не тільки веде дитину веселковими стежками у чарівну країну, де тварини і рослини живуть як люди, в радощах і турботах, але, слухаючи казки, дитина дістає приклади образної мови, запам'ятовує нові слова, їі мова стає багатшою і правильнішою» [4, с.47].

У розділі «Спів і музика» авторка констатує: «У тому садку діти добре себе почувають, в якому часто дзвенить веселий дитячий спів. Дитина народжується 3 любов’ю до співу й музики. Вже немовлятко із задоволенням слухає колискової пісеньки i, вколисане їі мелодією, спокійно засинає. Старші діти передають через спів і музику свої настрої і переживання. Приспівуючи, вони рухами виявляють свою радість, вдоволення, притупцьовують ногами, 
стрибають, присідають, плещуть у долоні» [4, с.53]. Відповідно до методичних рекомендацій, поданих у посібнику, музичне виховання в дитячому садку має такі види: спів (як основа всієї музичної праці з малими дітьми) та ритміка (окремо визначеного місця в робочому плані для такого виду роботи немає, проте найчастіше використовується для заспокоєння вихованців перед проведенням якогось заняття, що потребує зосередження та заспокоєння) [4, с.54]. Наступними видами музичного виховання $\epsilon$ рухи під музику та ігри зі співомінтерпретація тексту і характеру музичного твору рухами тіла, ілюстрування змісту пісні. Діти, які часто слухають музику, охоче самі ілюструють рухами виразний музичний текст, а виховниця тільки радить, якщо є така потреба, та «відшліфовує цілісність» [4, с.55]. У програмі святкових днів зазвичай виконуються різного роду таночки, які діти радо виконують. М. Пастернакова застерігає від занадто складних рухів, а лише ті, які дітям легко відтворити: присідання, висування кроків уперед, повороти в сторони, дрібні кроки 3 пригинанням колін, підстрибування - 3 таких елементі можна скласти танок під народну музику, зокрема коломийку; такий вид заняття потребує контролю з боку вихователя, щоб не відійти від задуму народного танцю. Слухання музики у виконанні дорослих - вид музичного заняття, який авторка рекомендує використовувати частіше, оскільки дітям подобається слухати, як співає вихователь, особливо, якщо спів відбувається без музичного супроводу. Велику радість дітям приносить ілюстрування музикою знайомих їм казок, наприклад «Ріпка», «Івасик Телесик», музична інтерпретація їх дітям дошкільного віку, можливо, навіть цікавіша за мовну, бо вона яскравіша, пластичніше відкриває перед їхніми очима казкові картини [4, с.56].

У розділі «Природознавство» Марія Пастернакова наголошує, що дітей треба виховувати якнайближче до природи, бо вона повна цікавих явищ у рослинному і тваринному світі. Вона $є$ не тільки могутнім засобом розумового розвитку вихованців, не тільки спряє ростові фізичних сил, але також дає естетичні переживання, які облагороджують дитяче серце [4, с.58]. «Найважливіше, - переконує Пастернакова М., - допомогти дитині навчитися спостерігати, бо вслід за тим піде допитливість, непомітно збудиться жадоба до знання, тому у кожній порі року, коли тільки до того пригожі атмосферні умови, треба виходити з дітьми на прогулянку в природу, щоб вони мали змогу робити спостереження на конкретному матеріалі» [4, с.58-59]. Авторка подає тематичні напрямки, як приклади, де і за яких умов можна проводити 3 дітьми цільові екскурсії до природничих об'єктів у різні пори року. Приміром, навесні дітям велику втіху приносить спостереження за появою перших листочків, квітів, з їх допомогою вони пізнають поняття кольору, запаху, форми і розміру; прислухаючись до щебету пташок - вправляють свій слух i водночас дізнаються про особливості їх гніздування і способу життя. Радісним вигукуванням вітають вихованці перших метеликів, жуків, із захопленням спостерігають за їх рухливим життям. Приглядаючись до праці дорослих, діти й собі починають «веснувати», а далі доглядати за своєю городиною [4, с.59]. 
Улітку дітей можна вивести у поле, де вони готують квіти для гербарію, вчаться плести віночки, у бесідах дізнаються, звідки береться хліб і кому взимку стануть у нагоді запаси сіна, діти співають обжинкових пісень i слухають розповідь про працю рільника. 3 таких прогулянок дошкільники повертаються, стверджує М. Пастернакова, дуже щасливими.

Прекрасною темою для бесіди та об'єктами для спостереження восени може бути зміна забарвлення листя на дереві; разом 3 дітьми можна спостерігати за відльотом птахів, плетінням павутини, листопадом. Цікавим видом роботи у природі є збирання жолудів, каштанів, шишок, горіхів, опалого листя, насіння дині і соняшника, плодів шипшини; цей природній матеріал буде служити «сировиною» для виготовлення іграшок-саморобок [4, с.61-62]. Авторка рекомендує долучати дітей старшого дошкільного віку до збору фруктів у саду.

У зимову пору діти залюбки слухають казки у вечірні години, згадуючи про літні прогулянки та пригоди. Корисною є бесіда про властивості снігу і льоду, які вони можуть принести у групову кімнату i, нагрівши при кімнатній температурі, отримати воду. У цю пору року дітей так само долучають до виконання посильної праці- замести доріжки від снігу, насипати корм для птахів у годівнички.

Марія Пастернакова стверджує, що безпосередня зустріч дітей з природою дає їм багато вражень і знання, сприяє вихованню спостережливості, дарує поштовх до різноманітних ігор [4, с.63]. Якщо ж із якоїсь причини стає неможливою прогулянка на свіжому повітрі, тоді вихованців долучають до «плекання» кімнатних рослин: полив, пересаджування, витирання листочків; якщо дозволяють умови - можна в груповій кімнаті організувати акваріум із рибками. «Виховниця дитячого садка повинна знати, що природа дає дітям безліч емоційних вражень, розгортає перед ними щораз нові цікаві світи. Запитання дітей $\epsilon$ показником того, що їм було цікаво, їх враження - позитивні, тому ї допитливість варто підтримувати зрозумілими та доступними вихованцям відповідями» [4, с.64].

«Характерною прикметою малої дитини є іï нестримний гін до руху, діяльності. Вона не може безчинно сидіти довго на одному місці, не може теж довго залишатися в пасивній ролі глядача. Мусить невпинно чимось займатися, щоб таким способом виявити своє враження від навколишнього світу, найти справжній вихід своїй живій уяві. Одним із найулюбленіших засобів прояву своєї думки для дітей $є$ рисунок» [4, с.65]. У своєму посібнику М. Пастернакова детально описує всі етапи становлення дитячого малюнка, використовуючи знання дитячої психології. У методичних вказівках для вихователя авторка рекомендує 3 обережністю керувати розвитком дитячої творчості, підтримувати ініціативу, допомагати вихованцям доводити справу до завершення, при цьому не нав'язувати дитині своєї думки. «Малюнки дитячі - це наче документи, які стверджують розумовий розвиток дитини, тому малюнки конче треба систематично збирати, зберігати, аналізувати, робити 3 
них висновки»,- рекомендує Марія Іванівна [4, с.66]. 3 цієї причини варто складати всі роботи кожного вихованця уже 3 перших днів перебування у садочку в окрему папку, попередньо підписавши дату і вказавши, що зображено на аркуші. Перегляд такої збірки надає можливість глибше пізнати кожну дитину, ii зацікавлення, мистецький смак, технічні здібності. Така оцінка дитячої творчості, на переконання М. Пастернакової, дає велику допомогу у виховній праці з дітьми дошкільного віку, дає можливість індивідуального підходу до кожного вихованця [4, с.67].

Заняття із зображувальної діяльності можуть бути на вільну тему чи на тему, запропоновану вихователем. В обох випадках рекомендується попередньо приготувати усі необхідні матеріали.

Дорадно, що в українських садочках в діаспорі практикувалося малювання не лише на папері. Як описує у своїх методичних рекомендаціях Марія Пастернакова: «Дуже бажано, щоб у дит. садках були великі чорні з лінолеуму чи лаковані таблиці, прикріплені до стіни на висоті приблизно 1 м. Крім організованих занять, діти радо під час довільних ігор підходять до таблиці і кольоровими олівцями малюють, що самі хочуть. Це заохочує дитину до образотворчої праці, удосконалює іiї техніку, розвиває творчу уяву» [4, с.68].

Крім малювання авторка звертає увагу й на інші улюблені дитячі заняття: моделювання $з$ піску (наголошується, що цей матеріал допомагає розвивати не тільки орган дотику, але і сприяє розвитку творчості та фантазії). Крім звичного способу використання піску на майданчику, автором подаються рекомендації до застосування піску у приміщенні групової кімнати, щоб діти могли його використовувати не тільки у теплу пору року. Іншими матеріалами, які пропонуються педагогом, $є$ глина і пластилін. У методичних вказівках подаються чіткі вимоги до облаштування та знаряддя, які потрібні для таких занять, зокрема: дощечки чи відрізок лінолеуму розміром $30 \mathrm{x} 40 \mathrm{~cm}$, об'єм глини або пластиліну для роботи - розміром 3 кулак дитини, щоб вона мала можливість працювати не тільки пальчиками, а могла діяти всією долонею [4, с.69].

У розділі «Святкові дні в дитячому садку» авторка слушно зауважує, що імпрези (свята - авт.) проводяться з метою популяризації дошкільної справи і приносить дітям багато радощів та приємних переживань, позитивних емоцій. Під час проведення свят $\epsilon$ добра нагода для розвитку дитячих талантів, вони сприяють розвитку дитячої сміливості, товариськості $[4$, с.76]. Далі подаються чіткі рекомендації для проведення окремих свят, зокрема: «Тарасове Свято», «Свято Слави», «Січових Стрільців», «Свято Матері», «Ялинка», «Св. Миколая», «Свято Весни», «Базар» та ін.

Виховниця дає поради по облаштуванню святкової зали, приготування тематичних костюмів, методичні рекомендації до проведення усіх святкових дійств [4, с.79-80].

Отже, можемо констатувати, що ані вимушене прощання з рідною землею, ані воєнні події чи важкі години перебування разом із чоловіком на північно- 
американському континенті не завадили М. Пастернаковій втілити свої плани в життя навіть через десяток років, перебуваючи за океаном, на іншому континенті. Методичний посібник «Зайняття в дитячому садку» став насправді вагомим доробком у галузі дошкільної педагогіки, а в українській діаспорі країни кленового листу - тим паче; він абсолютно вірно був названий «Азбукою дошкілля» для усіх українських педагогів-дошкільників, виховниць, для українських педагогів у вільному світі.

Висновки. Марія Іванівна Пастернак - відома не тільки як науковець, педагог в Україні, яка мала великий літературний та науковий доробок; вона ще й зробила значний внесок як виховниця - у розвиток української дошкільної педагогіки в українській діаспорі Канади, а саме теорію та практику організації дошкілля в країні кленового листу.

\section{Лimepamypa:}

1. Бура Л. (Бурачинська Л.) Невтоптаними стежками. Наше Життя. 1966. №7. С. 9-10. Режим доступу: URL: https://unwla.org/media/magazine/our-life/196x/1966-07-julymagazine-Our-Life.pdf

2. Дзвінка Воробкало. Філософія танцю Марії Пастернак. Режим доступу: URL:

https://zbruc.eu/node/69980

3. Завгородня Т.К., Пахолок Р.І. Науково-освітня діяльність Марії Пастернак (18971983 рр.). Педагогічні науки: зб. наук. пр. Херсон, 2013. Вип. 63. С. 10-14.

4. Пастернакова М. Зайняття в дитячому садку (Методичні вказівки). Торонто: Об’єднання українських педагогів Канади. 1959. 80 с.

5. Пастернакова М. Який посів - такі жнива. Збірник доповідів, виголошених на Сесії для справ Українського дошкілля в Торонті, 14 і 15 травня 1965 р. Торонто, Об’єднання Українських Педагогів Канади. 1965. С. 21-29.

\section{References:}

1. Bura L. (Burachy`ns`ka L.) (1966). Nevtoptany`my` stezhkamy`[By tireless paths]. Nashe Zhy'ttya, 7. 9-10. Retrieved from: https://unwla.org/media/magazine/our-life/196x/1966-07-julymagazine-Our-Life.pdf [in Ukrainian].

2. Dzvinka Vorobkalo. Filosofiya tancyu Mariyi Pasternak [Maria Pasternak's philosophy of dance]. Retrieved from: https://zbruc.eu/node/69980 [in Ukrainian].

3. Zavgorodnya, T., \& Paxolok R. (2013). Naukovo-osvitnya diyal'nist` Mariyi Pasternak (1897-1983) [Research and educational activities of Maria Pasternak]. Pedagogichni nauky: $z b$. nauk. pr. Xerson, 2013, 63. 10-14 [in Ukrainian].

4. Pasternakova, M. (1959). Zajnyattya v dy`tyachomu sadku (Metody 'chni vkazivky'). [Classes in Kindergarten] (Guidelines). Toronto: Ob'yednannya ukrayins`ky`x pedagogiv Kanady`. 80. [in Ukrainian].

5. Pasternakova, M. (1965). Yaky`j posiv - taki zhny`va. Zbirny`k dopovidiv, vy'golosheny`x na Sesiyi dlya sprav Ukrayins kogo doshkillya v Toronti, 14 i 15 travnya $1965 \mathrm{r}$. [What sowing - is such a harvest. Collection of reports delivered at the Session for Ukrainian Preschool Affairs in Toronto, May 14,15, 1965]. Toronto, Ob'yednannya Ukrayins ky`x Pedagogiv Kanady’, $21-29$ [in Ukrainian]. 